\title{
FAKTOR YANG MEMPENGARUHI IMPLEMENTASI \\ PROGRAM KELUARGA HARAPAN (PKH) DI KECAMATAN POASIA KOTA KENDARI SULAWESI TENGGARA
}

\author{
${ }^{1}$ Meti Asnia, ${ }^{2}$ Mustakim, ${ }^{3}$ Suryani BB \\ 1,2,3 Fakultas IImu Sosial dan IImu Politik, Universitas Halu Oleo \\ mestiasnia@gmail.com, suriyanibb@gmail.com
}

\begin{abstract}
This study aims to determine factors affecting implementation Hope family program (pkh) in poasia district Kendari City, Southeast Sulawesi. The approach of this research is a qualitative approach with descriptive qualitative research. The technique of collecting data is done through observation, interviews, and documentation. The data analysis technique used consists of data collection, data reduction, data presentation and conclusion drawing. The results of this study indicate that the implementation of the PKH policy in Poasia District, in general, has not been implemented properly based on PKH knowledge and socialization carried out by the facilitator; Validation process in determining PKH participants; The process of distributing PKH funds to PKH recipients is carried out through the channelling bank; The obligation of PKH participants to carry out their obligations has not been well understood; while the factors that influence the implementation of the program do not always affect. The conclusion of the study shows that the implementation of the Family Hope Program policy in Poasia District, in general, has not been implemented well.
\end{abstract}

Keywords: Implementation; Policy; Hope Family Program;

\begin{abstract}
Abstrak
Penelitian ini bertujuan untuk mengetahui faktor-faktor yang mempengaruhi implementasi Program Keluarga Harapan (PKH) di Kecamatan Poasia.

Pendekatan penelitian ini adalah pendekatan Kualitatif dengan jenis penelitian deskriptif Kualitatif. Teknik pengumpulan data dilakukan melalui observasi, wawancara, dan dokumentasi. Teknik analisis data yang di gunakan terdiri dari pengumpulan data, reduksi data, penyajian data dan penarikan kesimpulan. Hasil penelitian ini menunjukan bahwa Implementasi kebijakan Program Keluarga harapan (PKH) di Kecamatan Poasia secara umum belum terlaksana dengan baik berdasarkan pengetahuan dan sosialisasi PKH yang dilakukan oleh pendamping; Proses validasi dalam menentukan peserta PKH; Proses pendistribusian dana PKH kepada penerima PKH dilakUkan melaui bank penyalur; Kewajiban peserta PKH dalam melaksanakan kewajibannya belum memahami dengan baik; sedangkan faktor yang mempengaruhi implementasi program tidak selalu mempengaruhi. Kesimpulan penelitian menunjukan bahwa Implementasi kebijakan Program Keluarga harapan (PKH) di Kecamatan Poasia secara umum belum terlaksana dengan baik.
\end{abstract}

Kata kunci: Implementasi; Kebijakan; Program Keluaga Harapan; 
Vol 2 No 3 August-October 2019. pp. 42 - 56 Journal PUBLICUHO Faculty of Social and Political Sciences Halu Oleo University, Kendari, Southeast Sulawesi, Indonesia. ISSN 2621-1351 (online), ISSN 2685-0729 (print) Open Access at: http://ojs.uho.ac.id/index.php/PUBLICUHO/index

\section{PENDAHULUAN}

Pemerintah Indonesia mangadopsi Program Keluarga harapan (PKH) atau Conditional Cash Transfer (CCT) yang dikenal didunia dalam menanggulangi kemiskinan yang kronis sebagai bentuk penanggulangan sosial. PKH pertama kali diimplementasikan di sejumlah Negara Amerika Latin dan Karibia seperti, Meksiko, Brazil, Kolumbia, Honduras, Jamaica, dan Nikaragua. Program ini tergolong berhasil menurunkan angka kemiskinan.

Sejak tahun 2007 pemerintah Indonesia melalui Kementrian Sosial telah mengklaim melaksanakan Program Bantuan Tunai Bersyarat (BTB) yang dikenal dengan nama Program Keluarga Harapan (PKH) tersebut. PKH adalah suatu program yang memberikan bantuan tunai kepada keluarga miskin, jika mereka memenuhi persyaratan yang terkait dengan peningkatan kualitas sumberdaya manusia (SDM), yaitu pendidikan, kesehatan dan kesejahteraan sosial. Tujuan utama PKH adalah meningkatkan aksebilitas terhadap pelayanan pendidikan, kesehatan dan kesejahteraan sosial dalam mendukung tercapainya kualitas hidup keluarga miskin. PKH diharapakan dapat mengurangi beban pengeluaran keluarga miskin dalam jangka pendek serta memutus rantai kemiskinan dalam jangka penjang. Sasaran penerima PKH adalah Keluarga Miskin (KM) yang memenuhi minimal satu dari kriteria yang terdiri dari anak usia 0-21 tahun, ibu hamil/nifas, Lansia diatas 70 tahun dan Disabilitas Berat.

Permasalahan kemiskinan juga terjadi di Provinsi Sulawesi Tenggara. Berdasarkan Badan Pusat Statistik Sulawesi Tenggara Pada periode September 2014-September 2016 jumlah penduduk miskin mengalami peningkatan sebesar 13,20 ribu orang, yaitu dari 314,09 ribu orang pada September 2014 menjadi 327,29 ribu orang pada September 2016. Persentase penduduk miskin relatif tidak berubah pada nilai 12,77 persen pada periode yang sama (Badan Pusat Statistik Tahun 2017). Demikian halnya dengan Kota Kendari merupakan ibukota provinsi Sulawesi Tenggara. Penduduk Kota Kendari berdasarkan proyeksi penduduk tahun 2016 sebanyak 359.371 jiwa yang terdiri atas 181.392 jiwa penduduk laki-laki dan 177.979 jiwa penduduk perempuan. Dibandingkan dengan proyeksi jumlah penduduk tahun 2015, penduduk Kota Kendari mengalami pertumbuhan sebesar 3,42 persen dengan masingmasing persentase pertumbuhan penduduk laki-laki sebesar 3,45 persen dan penduduk perempuan sebesar 3,38 persen. Sementara itu besarnya angka rasio jenis kelamin tahun 2016 penduduk laki-laki terhadap penduduk perempuan sebesar 101,92 (Badan Pusat Statistik Kota Kendari 2017).

Tingginya pertumbuhan penduduk di Kota Kendari salah satunya dipengaruhi oleh arus urbanisasi mengingat kota Kendari adalah ibu kota dari Sulawesi Tenggara. Diantara urban berpotensi menyumbang angka kemiskinan dan permaslahan kesejahteraan sosial lainnya. Jumlah penduduk miskin kota Kendari sebanyak 18.044 jiwa (Badan Pusat Stastistik Kota Kendari 2017)

Dengan adanya Program Keluarga Harapan (PKH) diharapakan dapat mengurangi kemiskinan yang ada di Kota Kendari. Pelaksanaan PKH di Kota Kendari dimulai sejak tahun 2012. Berdasarkan data Dinas Sosial UPPKH Kota Kendari tahun 2018 jumlah penerima PKH Kota Kendari berjumlah 7.470 orang.

Menurut Elwan L.O.M (2019: Journal Publicuho, 2(1), 15-29), Predikat Kota Layak Anak Kota Kendari merupakan prestasi baik sebagai salah satu yang mewakili Provinsi Sulawesi Tenggara. Namun untuk mencapai Kota Layak Anak harus mencapai 50 persen dari seluruh indikator dalam Klaster yang sudah ditetapkan pemerintah. Penerapan dan penetapan kecamatan ramah anak guna mendukung Kota Kendari menjadi kota layak anak kategori utama. Predikat KLA diatas dilakukan berdasarkan Peraturan Menteri Negara Pemberdayaan Perempuan dan Perlindungan Anak Republik Indonesia Nomor 12 Tahun 2011 tentang Indikator Kabupaten/Kota Layak Anak berdasarkan Klaster dan indikator yang kemudian 
digunakan sebagai standar penilaian Kota Layak Anak bagi Pemerintah Kabupaten/Kota di Indonesia.

Penilaian tersebut merupakan penilaian tim evaluasi independen yang terdiri dari pakar anak, akademisi, dan praktisi pemerhati hak anak dari Kementerian PP-PA yang dinilai dari seberapa besar pemenuhan hak-hak anak berdasarkan indikator KLA tresebut. Hanya saja, belum ada data yang jelas mengenai bentuk penilaian terkait kriteria kabupaten/kota yang meraih penghargaan KLA, baik kategori pratama, madya, maupun nindya sehingga cenderung menimbulkan asumsi bahwa pemberian penghargaan kepada sebuah kabupaten/kota tidak sepenuhnya murni bahwa kabupaten/kota yang bersangkutan sejatinya benar-benar memenuhi hak-hak anak di daerahnya, kadangkala hal itu lebih karena faktor politis.

Lebih lanjut, Menurut Elwan L.O.M (2019: Journal Publicuho, 2(1), 15-29, menyatakan bahwa pemgembangan KLA di Kota Kendari bukan tanpa hambatan. Masih terdapat beberapa masalah dalam pelaksanaannya. Hasil observasi awal mengenai Kebijakan Pengembangan KLA di Kota Kendari, ditemukan beberapa masalah, antara lain sebagai berikut.

Pertama, presentase pertumbuhan penduduk di Kota Kendari mengalami kenaikan yang signifikan antara tahun 2015-2017.

Kedua, Kota Kendari sampai dengan tahun 2018 belum memiliki data permanen jumlah pekerja anak dan anak jalanan. Kota Kendari hanya memiliki data Pekerja Anak dan Anak Jalan pada dinas atau badan tertentu yang melakukan penelitian pada kedua masalah anak-anak pada wilayah tertentu. Kondisi tampak banyak jenis pekerjaan di sektor jasa yang dilakukan oleh anak-anak di bawah umur 18 tahun. Berikut data profile pekerja anak Kota Kendari Tahun 2017 di sajikan pada Gambar 1.

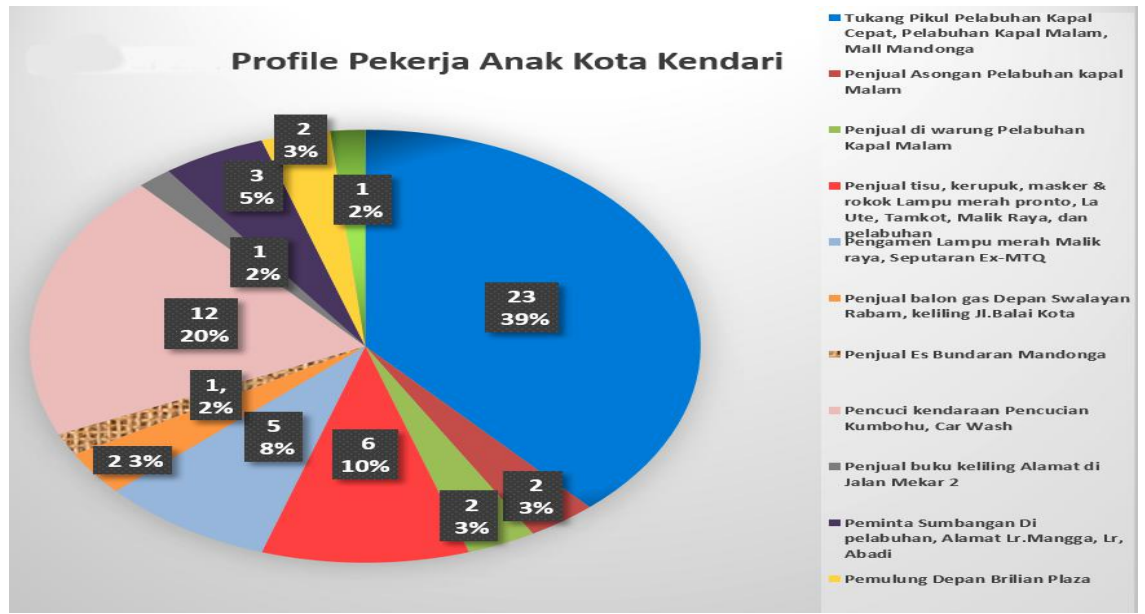

Gambar 1. Profile Pekerja Anak Kota Kendari Tahun 2017

Sumber: Elwan, dalam Laporan Penelitian Kerjasama Bappeda Kota Kendari 2017.

Ketiga, masalah lingkungan keluarga anak yang broken home dan pengasuhan alternatif yang salah digunakan oleh majikan.

Keempat, belum terpenuhi kesehatan dasar akibat dari kondisi rumah dan lingkungan yang masih kumuh dan kotor dan kesejahteraan yang belum terpenuhi akibat dari penghasilan rumah tangga yang minim akibat tidak adanya jaminan pekerjaan yang layak

Kelima, masih banyak anak yang tidak sekolah, putus sekolah dan tidak mampu melanjutkan pendidikan di perguruan tinggi/universitas, pemanfaatan waktu luang atau masa bermain yang tidak terpenuhi akibat dari anak-anak harus bekerja membantu orangtua menambah penghasilan rumah tangga dengan jam kerja yang melebihi jam kerja orang dewasa.

Keenam, perlindungan khusus yang tidak tepat sasaran antara lain pemenuhan hak anak untuk hidup aman dan damai. Perlindungan dari eksploitasi anak, baik dari orangtua/majikan, atau jaringan pekerja anak ilegal pda berbagai sektor jasa.

Ketujuh, Rumah singgah bagi anak jalan belum dikelolah secara maksimal. Akibatnya, anak jalan selalu saja melarikan diri atau minggat atas kemauan sendiri dan rata-rata adalah mereka berstatus sebagai pekerja anak yang membantu menambah penghasilan keluarganya. 
Vol 2 No 3 August-October 2019. pp. 42 - 56 Journal PUBLICUHO Faculty of Social and Political Sciences Halu Oleo University, Kendari, Southeast Sulawesi, Indonesia. ISSN 2621-1351 (online), ISSN 2685-0729 (print) Open Access at: http://ojs.uho.ac.id/index.php/PUBLICUHO/index

Kedelapan, kurangnya peran aktif Satuan Tugas Perlindungan Anak (Satgas PA) di tingkat RW dalam melakukan sosialisasi dan konseling dalam mencegah kasus Kekerasan Dalam Rumah Tangga (KDRT) termasuk kekerasan terhadap anak.

Kesembilan, kurangnya koordinasi antar Gugus Tugas Kota Layak Anak Kota Kendari. Selain itu, kurangnya koordinasi juga terlihat dari beberapa SKPD yang belum paham betul akan tugas pokok dan fungsinya dalam Gugus Tugas Kota Layak Anak (KLA).

Karakter masalah tersebut, sedapat mungkin bisa terjawab melalui sinergitas program pemerintah pusat dan daerah melalui Program Kota Layak Anak. Pengembangan KLA di Indonesia masih dilakukan secara parsial di beberapa kota yang besar terbilang jauh lebih kompleks dibanding dengan pengembangan sebuah kota yang layak bagi anak di negara lain.

Demikian halnya dengan Kecamatan Poasia di Kota Kendari yang melaksanakan Program Keluarga Harapan yaitu Kecamatan Poasia. Jumlah Penduduk Kecamatan Poasia berjumlah 31.933 jiwa (Badan Pusat Stastistik 2017). Pelaksanaan PKH di Kecamatan Poasia mulai dilaksanakan sejak tahun 2012. Jumlah penerima PKH dikecamatan Poasia berdasarkan data Dinas Sosial UPPKH Kota Kendari tahun 2018 sebanyak 854 orang terdiri dari Kelurahan Anduonohu 279 orang; Kelurahan Anggoeya 265 orang; Kelurahan Rahandouna 222 orang; Kelurahan Matabubu 88 orang. Pelaksanaan PKH di Kecamatan Poasia sudah berjalan enam (6) tahun.

Berdasarkan uraian latar belakang tersebut, peneliti tertarik untuk malakukan penelitian mengenai Implementasi Program Keluarga Harapan (PKH) di Kecamatan Poasia Kota Kendari.

\section{TINJAUAN PUSTAKA}

\section{A. Pengertian Implementasi Kebijakan}

Implementasi kebijakan merupakan alat administrasi hukum dimana berbagai aktor, organisasi, prosedur, dan teknik yang bekerja bersama-sama untuk menjalankan kebijakan guna meraih dampak atau tujuan yang diinginkan (Winarno 2005:101).

Nugroho (2009: 494) menyatakan bahwa,Implementasi kebijakan publik pada prinsipnya adalah cara agar sebuah kebijakan dapat mencapai tujuannya. Tidak lebih tidak kurang. Untuk mengimplementasikan kebijakan, ada dua pilihan langkah yang ada, yaitu langsung mengimplementasikan dalam bentuk program atau melalui formulasi kebijakan derivat atau turunan dari kebijakan tersebut.

Widodo (2001: 191) menyaakan bahwa, Sebuah kebijakan publik yang telah disahkan tidak akan bermanfaat apabila tidak diimplementasikan. Hal ini disebabkan karena implementasi kebijakan publik berusaha mewujudkan kebijakan publik yang masih bersifat abstrak ke dalam realitas nyata. Dengan kata lain, pelaksanaan kebijakan publik berusaha menimbulkan hasil (outcome) yang dapat dinikmati terutama oleh kelompok sasaran (target groups).

Van Mater dan Van Horn (dalam Widodo 2001: 192) menyatakan bahwa, Implementasi kebijakan menekankan pada suatu tindakan, baik yang dilakukan oleh pihak pemerintah maupun individu (atau kelompok) swasta, yang diarahkan untuk mencapai tujuan-tujuan yang telah ditetapkan dalam suatu keputusan kebijakan sebelumnya.

Definisi implementasi berikutnya diungkapkan Daniel Mazmanian dan Paul Sebatier (dalam Agustino, 2006:153), yang mendefinisikan implementasi kebijakan adalah" pelaksanaan keputusan kebijakan dasar, biasanya dalam bentuk Undang-Undang, namun dapat pula berbentuk perintah atau keputusan-keputusan eksekutif yang penting atau keputusan badan peradilan. Lazimnya keputusan tersebut mengidentifikasi masalah yang ingin diatasi, menyebutkan secara tegas tujuan dn sasaran yang ingin dicapai, dan berbagai cara untuk menstrukturkan atau mengatur proses implementasinya".

Dari berbagai pendapat mengenai implementasi kebijakan dari para ahli diatas, implementasi kebijakan pada prinsipnya adalah cara agar sebuah kebijakan dapat mencapai tujuannya. Sebuah kegiatan untuk mendistribusikan keluaran kebijakan yang 
dilakukan oleh para implementer kepada kelompok sasaran sebagai upaya mewujudkan tujuan kebijakan.

\section{B. Fakłor-Faktor Yang Mempengaruhi Keberhasilan Implementasi Kebijakan}

Faktor-faktor yang mempengaruhi keberhasilan implemantasi kebijakan menurut Van Meter dan Van Horn (Wahab 2012:165) yaitu:

1. Standar/ ukuran dan tujuan kebijakan

Implementasi kebijakan dapat diukur tingkat keberhasilannya dari ukuran dan tujuan kebijakan. Setiap kebijakan publik harus mempunyai standar dan sasaran kebijakan secara jelas. Dengan ketentuan tersebut tujuannya dapat tercapai. Ketika suatu kebijakan tidak memiliki standar dan sasaran yang jelas maka akan menimbulkan kesalahpahaman dan konflik dalam pelaksanaannya.

2. Sumber-sumber kebijakan

Perlunya dukungan dan memanfaatkan sumber daya yang tersedia, baik sumber daya manusia yang berkualitas dan sumber daya finansial.

3. Ciri-ciri atau karakteristik badan/ instansi pelaksana

Dalam suatu implementasi kebijakan karakteristik pelaksana harus tepat dengan kebijakannya yang mencakup struktur birokrasi, norma-norma dan pola-pola hubungan yang terjadi dalam birokrasi, karena akan mempengaruhi implementasi suatu program kebijakan.

4. Komunikasi antar organisasi terkait dan kegiatan-kegiatan pelaksanaan Komunikasi antar organisasi terkait dan kegiatan-kegiatan pelaksanaan agar kebijakan publik bisa dilaksanakan dengan efektif, apa yang menjadi standar tujuan harus dipahami oleh para implementor yang bertanggung jawab atas pencapaian standar dan tujuan kebijakan, karena itu komunikasi dan kordinasi merupakan hal yang pentinh agar tujuan dan sasaran dapat tercapai.

5. Sikap para pelaksana

Sikap penerimaan atau penolakan dari pelaksana kebijakan sangat mempengaruhi keberhasilan atau kegagalan implementasi kebijakan publik. Sikap para pelaksana diawali penyaringan lebih dahulu melalui persepsi dari pelaksana dalam batas mana kebijakan itu dilaksanakan. Terdapat tiga macam elemen respon yang dapat mempengaruhi kemampuan dan kemauannya untuk melaksanakan suatu kebijakan, antara lain terdiri dari pengetahuan, pemahaman dan pendalaman terhadap kebijakan. Kedua, arah respon mereka apakah menerima, netral atau menolak dan ketiga, intensitas terhadap kebijakan. Implementasi kebijakan yang berhasil bisa jadi gagal karena tidak sepenuhnya menyadari standar dan tujuan kebijakan dan mungkin dikarenakan mereka menolak apa yang menjadi tujuan suatu kebijakan. Sebaliknya apabila sikap para pelaksana bertanggung jawab untuk melaksanakan kebijakan tersebut maka implementasi kebijakan akan berhasil.

6. Lingkungan ekonomi, sosial dan politik

Kondisi sosial ekonomi sebuah masyarakat yang maju, sistem politik yang stabil dan demokratis, dukungan baik dari konstituen maupun elit penguasa dan budaya keseharian masyarakat yang mendukung akan mempermudah implementasi sebuah kebijakan.

\section{Faktor-Faktor yang mempengaruhi Kegagalan Implementasi}

Makinde dalam Agus dan Ratih (2012:85) mengidentifikasi kegagalan implementasi disebabkan oleh :

1. Kelompok sasaran tidak terlibat dalam implementasi program

Bagaimana mungkin suatu implementasi program dapat berhasil apabila kelompok sasarannya tidak terlibat.

2. Program yang diimplementasikan tidak mempertimbangkan kondisi lingkungan sosial, ekonomi dan politik.

Kondisi lingkungan sosial dan ekonomi yang kondusif serta masyarakat yang sudah terbuka dan terdidik relatif lebih mudah menerima program pembaruan dibanding dengan masyarakat yang masih tertutup dan tradisional.

3. Adanya korupsi

Penyalahgunaan amanah untuk kepentingan pribadi. Serangkaian tindakan-tindakan terlarang atau melawan hukum dalam rangka mendapatkan keuntungan dengan merugikan orang lain. Hal yang paling mengidentikkan perilaku- perilaku korupsi 
Vol 2 No 3 August-October 2019. pp. 42 - 56 Journal PUBLICUHO Faculty of Social and Political Sciences Halu Oleo University, Kendari, Southeast Sulawesi, Indonesia. ISSN 2621-1351 (online), ISSN 2685-0729 (print) Open Access at: http://ojs.uho.ac.id/index.php/PUBLICUHO/index

bagi masyarakat umum adalah penekanan pada penyalahgunaan kekuasaan atau jabatan public untuk keuntungan pribadi.

4. Sumberdaya manusia yang kapasitasnya rendah

Kebijakan yang tidak didukung oleh sumber daya manusia yang tepat akan sulit merealisasikan tujuan-tujuannya.

5. Tidak adanya koordinasi dan monitoring

Koordinasi dan monitoring sangat penting diantara lembaga-lembaga pelaksana dan dengan penerima layanan.

\section{Model- Model Implementasi Kebijakan Publik}

Model kebijakan adalah representasi sederhana mengenai aspek-aspek yang dipilih dari suatu kondisi masalah yang disusun untuk tujuan-tujuan tertentu. Model kebijakan merupakan penyederhanaan system masalah dengan membantu mengurangi kompleksitas dan menjadikannya dapat dikelola oleh para analis kebijakan. Model digunakan sebagai pedoman dalam penelitian yang bertujuan untuk mengadakan penggalian atau penemuanpenemuan baru. Model menjadi pedoman untuk menemukan (to discover) dan mengusulkan hubungan antara konsep-konsep yang digunakan untuk mengamati gejala sosial (Wahab 2012:154). Berikut ini adalah macam-macam model kebijakan publik menurut para ahli, antara lain:

\section{a. Model Van Meter dan Van Horn}

Model ini merupakan model klasik, model ini mengandaikan bahwa implementasi kebijakan berjalan secara linier dari kebijakan publik, implementator dan kinerja kebijakan publik. Beberapa variable yang dimasukan sebagai variable yang mempengaruhi kebijakan publik adalah variable:

1. Aktivitas implementasi dan komunikasi antar organisasi

2. Karakteristik dari agen pelaksana/ implementor

3. Kondisi ekonomi dan politik

4. Kecenderungan dari pelaksana/ implementor

\section{b. Model Mazmanian dan Sabatier}

Model Mazmanian dan Sabatier disebut sebagai model kerangka analisis implementasi, model ini mengklasifikasikan proses implementasi kebijakan ke dalam tiga variable yaitu :

1. Variable Independen

Yaitu mudah tidaknya masalah dikendalikan yang berkenaan dengan indikator masalah teori dan teknis pelaksanaan, keragaman proyek dan perubahan seperti apa yang dikehendaki.

2. Variable Intervening

Yaitu variabel kemampuan kebijakan untuk menstrukturkan proses implementasi dengan indicator kejelasan dan konsistensi tujuan, dipergunakannya teori kausal, ketepatan alokasi sumberdana, keterpaduan hirarkis di antar lembaga pelaksana aturan pelaksana dari lembaga pelaksana dan perekrutan pejabat pelaksana dan keterbukaan kepada luar; dan variable di luar kebijakan yang mempengaruhi proses implementasi yang berkenaan dengan indicator kondisi sosio, ekonomi dan teknologi, dukungan publik, sikap dan risorsis dari konstituen, dukungan pejabat yang lebih tinggi dan komitmen serta kualitas kepemimpinan dari pejabat pelaksana.

3. Variable Depeden

Yaitu tahapan dalam proses implementasi dengan lima tahapan, yaitu pemahaman dari lembaga/ badan pelaksana dalam bentuk disusunnya kebijakan pelaksana, kepatuhan obyek, hasil nyata, penerimaan atas hasil nyata tersebut dan akhirnya mengarah kepada revisi atas kebijakan yang dibuat dan dilaksanakan tersebut ataupun keseluruhan kebijakan yang bersifat mendasar.

\section{c. Model Edward}

Menurut George Edward III dalam Widodo (2010:96) terdapat 4 faktor yng mempengaruhi keberhasilan atau kegagalan implementasi kebijakan antara lain yaitu sebagai berikut:

1. Komunikasi

Komunikasi diartikan sebagai "proses penyampaian informasi komunikator kepada komunikan". Informasi mengenai kebijakan publik menurut Edward III dalam 
Widodo (2010:97) perlu disampaikan kepada pelaku kebijakan agar para pelaku kebijakan dapat mengetahui apa yang harus mereka persiapkan dan lakukan untuk menjalankan kebijakan tersebut sehingga tujuan dan sasaran kebijakan dapat dicapai sesuai dengan yang diharapakan. Menurut Edward III dalam Widodo (2010:97), komunikasi kebijakan memiliki beberapa dimensi antara lain sebagai berikut:

1) Dimensi transmisi menghendaki agar kebijakan publik disampaikan tidak hanya disampaikan kepada pelaksana (implementors) kebijakan tetapi juga disampaikan kepada kelompok sasaran kebijakan dan pihak lain yang berkepentingan baik secara langsung maupun tidak langsung.

2) Dimensi kejelasan (clarity) menghendaki agar kebijakan yang ditrasmisikan kepada pelaksana, target grup dan pihak lain yang berkepentingan secara jelas sehingga diantara mereka mengetahui apa yang menjadi maksud, tujuan, sasaran, serta substansi dari kebijakan publik tersebut sehingga masing- masing akan mengetahui apa yang harus dipersiapkan serta dilaksanakan untuk mensukseskan kebijakan tersebut secara efektif dan efisien.

3) Dimensi konsistensi (consistency) diperlukan agar kebijakan yang diambil tidak simpang siur sehingga membingungkan pelaksana kebijakan, target grup dan pihak-pihak yang berkepentingan.

2. Sumberdaya

Menurut Edward III dalam Widodo (2010:98) mengemukakan bahwa faktor sumberdaya mempunyai peranan penting dalam implementasi kebijakan. sumberdaya tersebut meliputi sebagai berikut:

1) Sumberdaya Manusia Sumberdaya manusia merupakan salah satu variabel yang mempengaruhi keberhasilan pelaksanaan kebijakan.

2) Sumberdaya Anggaran Terbatasnya sumberdaya anggaran yang tersedia akan mempengaruhi keberhasilan pelaksanaan kebijakan. Disamping program tidak bisa dilaksanakan dengan optimal, keterbatasan anggaran menyebabkan disposisi para pelaku kebijakan rendah.

3) Sumberdaya Peralatan

Sumberdaya peralatan merupakan sarana yang digunakan untuk operasionalisasi impelementasi suatu kebijakan yang meliputi gedung,tanah, dan sarana yang semuanya akan memudahkan dalam memberikan pelayanan dalam implementasi kebijakan.

4) Sumberdaya Kewenangan

Pelaku utama kebijakan harus diberi wewenang yang cukup untuk membuat keputusan sendiri untuk melaksanakan kebijakan yang menjadi kewenangannya.

3. Disposisi

Pengertian disposisi dikatakan sebagai "kemauan, keinginan dan kecendrungan para pelaku kebijakan untuk melaksanakan kebijakan secara sungguh-sungguh sehingga apa yang menjadi tujuan kebijakan dapat diwujudkan".

4. Struktur Birokrasi

Salah satu aspek struktur yang penting dari setiap organisasi adalah adanya prosedur operasi standar (standard operating procedures atau SOP).

Dalam penelitian Implementasi kebijakan Program Keluarga Harapan (PKH) di Kecamatan Poasia Kota Kendari penulis mengacu pada model implementasi kebijakan yang dikemukakan George Edward III (dalam Widodo, 2010: 96).

\section{E. Program Keluarga Harapan (PKH)}

a. Pengertian Program Keluarga Harapan

Program Kelvarga Harapan (PKH) adalah program pemberian bantuan sosial bersyarat kepada keluarga miskin yang ditetapkan sebagai Keluarga Penerima Manfaat PKH

b. Tujuan Program Keluarga Harapan (PKH)

Adapun tujuan dari PKH yaitu sebagai beriku: 
Vol 2 No 3 August-October 2019. pp. 42 - 56 Journal PUBLICUHO Faculty of Social and Political Sciences Halu Oleo University, Kendari, Southeast Sulawesi, Indonesia. ISSN 2621-1351 (online), ISSN 2685-0729 (print) Open Access at: http://ojs.uho.ac.id/index.php/PUBLICUHO/index

1. Meningkatkan taraf hidup keluarga penerima manfaat melalui akses layanan pendidikan, kesehatan, dan kesejahteraan sosial

2. Mengurangi beban pengeluaran dan meningkatkan pendapatan keluarga miskin dan rentan

3. Menciptakan perubahan perilaku dan kemandirian keluarga penerima manfaat dalam mengakses layanan kesehatan dan pendidikan serta kesejahteraan sosial

4. Mengurangi kemiskinan dan kesenjangan antar kelompok pendapatan

c. Sasaran Program Keluarga Harapan (PKH)

Sasaran PKH merupakan keluarga dan/atau seseorang yang miskin dan rentan serta terdapat dalam data terpadu program penanganan fakir miskin. Keluarga penerima manfaat PKH adalah keluarga miskin yang memenuhi minimal satu kriteria sebagai berikut:

1. Kriteria komponen kesehatan yakni meliputi:

a. Ibu hamil/menyusui

b. Anak berusia 0 (nol) sampai dengan 6 (enam) tahun

2. Kriteria komponen pendidikan yakni anak usia 6 (enam) sampai dengan 21 (dua puluh satu) tahun yang belum menyelesaikan wajib belajar 12 (dua belas) tahun.

3. Kriteria komponen kesejahteraan yakni meliputi:

a. Lanjut usia minimal 60 (enam puluh) tahun

b. Penyandang disabilitas diutamakan disabilitas berat.

\section{F. Kerangka Pikir}

Dalam rangka percepatan pengentasan kemiskinan, pemerintah mempunyai banyak program yang bermuara pada masyarakat miskin salah satunya yakni Program Keluarga Harapan (PKH) yang berfokus meningkatkan taraf hidup keluarga penerima manfaat melalui akses layanan pendidikan, kesehatan, dan kesejahteraan sosial.

Alur pelaksanaan PKH dimulai dengan penetapan sasaran (targeting), pertemuan awal dan validasi, penyaluran bantuan, verifikasi komitmen, peningkatan kemampuan keluarga dan pemutakhiran data, (Dirjen Perlindungan dan Jaminan Sosial, 2016). Dalam penelitian ini hanya beberapa indikator pelaksanaan PKH yang diteliti seperti yang terlihat pada gambar kerangka pikir dibawah ini.

Menurut Edward (Widodo, 2010: 96), implementasi kebijakan dipengaruhi oleh 4 (empat) variabel, antara lain yakni; (1) Komunikasi yaitu keberhasilan implementasi kebijakan mensyaratkan agar implementator mengetahui apa yang harus dilakukan agar para pelaku kebijakan dapat mengetahui apa yang harus mereka persiapkan dan lakukan untuk menjalankan kebijakan tersebut sehingga tujuan dan sasaran kebijakan dapat dicapai sesuai dengan yang diharapakan.; (2) Sumberdaya adalah faktor penting untuk implementasi kebijakan agar efektif sumberdaya tersebut dapat berwujud sumberdaya manusia, sumberdaya anggaran, sumberdaya peralatan; (3) Disposisi adalah watak dan karakteristik yang dimiliki oleh implementator, seperti komitmen, kejujuran, dan sifat demokratis; (4) Struktur birokrasi yang bertugas mengimplementasikan kebijakan memiliki pengaruh yang signifikan terhadap implementasi kebijakan. Salah satu aspek struktur yang penting dari setiap organisasi adalah adanya prosedur operasi standar (standard operating procedures atau SOP).

Untuk lebih jelasnya, kerangka berpikir dalam penelitian ini akan di gambarkan sebagai berikut:

Alur Pelaksanaan PKH

- $\quad$ Pertemuan awal dan validasi

- Penyaluran Bantuan

- Verifikasi komitmen

(Dirjen Perlindungan dan Jaminan Sosial, 2016)
Faktor-faktor yang mempengaruhi Implementasi Kebijakan

1. Komunikasi

2. Sumber Daya

3. Disposisi

4. Struktur Birokrasi

Edward (Widodo, 2010: 96),

Gambar 2. Kerangka Berfikir 


\section{METODE PENELITIAN}

\section{A. TipePenelitian}

Tipe penelitian yang digunakan adalah penelitian deskriptif dengan pendekatan kualitatif. Arikunto (2005:234) menyatakan bahwa penelitian deskriptif merupkan penelitian yang dimaksudkan untuk mengumpulkan informasi mengenai status suatu gejala yang ada, yaitu keadaan gejala menurut apa adanya pada saat penelitian dilakukan

Bogdan dan Taylor dalam Moleong (2006: 4) menyatakan bahwa metodologi kualitatif merupakan prosedur penelitian yang menghasilkan data deskriptif berupa kata-kata tertulis atau lisan dan perilaku dari orang yang dapat diamati. Pendekatan ini diarahkan pada latar dan individu yang diteliti secara holistic.

Penelitian ini dilakukan di wilayah Kecamata Poasia, Kota Kendari Sulawesi Tenggara untuk mengetahui Implementasi Program Keluarga Harapan (PKH) di wilayah Kecamatan Poasia.

\section{B. Informan Penelitian}

Informan penelitian adalah orang yang dimanfaatkan untuk memberikan informasi tentang situasi dan kondisi latar belakang penelitian (Moleong 2000:97). Informan yaitu orang -orang yang sangat memahami permasalahan yang diteliti. Adapun informan dalam penelitian ini berjumlah 7 orang yang terdiri dari sebagai berikut: Koordinator PKH Kota Kendari, Camat Poasi, Pendamping PKH Kecamatan Poasia, dan Masyarakat penerima PKH sebanyak 4 orang

\section{Teknik Pengumpulan Data}

Teknik yang digunakan dalam pengumpulan data primer maupun data sekunder dilakukan dengan suatu penelitian secara seksama, yaitu dengan cara Observasi, Wawancara Mendalam, Dokumentasi.

\section{Teknik Analisis Data}

Analisis data kualitatif menurut Bogdan dan Biglen dalam Moleong (2006: 248) adalah upaya yang dilakukan dengan jalan bekerja dengan data, mengorganisasikan data, memilahmilah menjadi satuan yang dapat dikelola, mensintesiskannya, mencari dan menemukan pola, menemukan apa yang penting dan apa yang dipelajari, dan memutuskan apa yang dapat diceritakan kepada orang lain.

Miles dan Huberman (1992: 16-19) menyatakan bahwa analisis data terdiri dari tiga alur kegiatan yaitu Reduksi Data, Penyajian Data, Verifikasi dan Kesimpulan.

\section{HASIL DAN PEMBAHASAN}

\section{Implementasi Program Keluarga Harapan di Kecamatan Poasia}

Sasaran PKH merupakan keluarga dan/atau seseorang yang miskin dan rentan serta terdaftar dalam data terpadu program penanganan fakir miskin yakni ; (1). memiliki komponen kesehatan meliputi ibu hamil/ menyusui dan anak berusia 0 (nol) sampai dengan 6 (enam) tahun dan; (2) memiliki komponen pendidikan yang meliputi anak usia 6 (enam) sampai dengan 21 (dua puluh satu) tahun yang belum menyelesaikan wajib belajar 12 (dua belas) tahun; (3).komponen kesejahteraan sosial meliputi lanjut usia minimal dari 70 (Tujuh puluh) tahun dan penyandang disabilitas diutamakan penyandang disabilitas berat.

\section{Kelurahan Penerima Program Keluarga Harapan di Kecamatan Poasia}

Di Kecamtan Poasia yang berjumlah 5 Kelurahan, seluruhnya mendapat bantuan PKH. Kelurahan Anduonohu merupakan Kelurahan terbanyak yang mendapat bantuan PKH dengan jumlah 279 KPM sedangkan Kelurahan yang paling sedikit mendapatkan bantuan PKH adalah Kelurahan Matabubu dengan jumlah 88 KPM. Berikut tabel jumlah penerima pkh perkelurahan di Kecamatan Poasia. 
Vol 2 No 3 August-October 2019. pp. 42 - 56 Journal PUBLICUHO Faculty of Social and Political Sciences Halu Oleo University, Kendari, Southeast Sulawesi, Indonesia. ISSN 2621-1351 (online), ISSN 2685-0729 (print) Open Access at: http://ojs.uho.ac.id/index.php/PUBLICUHO/index

Tabel 1.

Jumlah Penerima PKH per-Kelurahan di Kecamatan Poasia Tahun 2018

\begin{tabular}{ccc}
\hline No & Kelurahan & Jumlah \\
\hline 1 & Anduonohu & 279 \\
\hline 2 & Anggoeya & 265 \\
\hline 3 & Rahandouna & 222 \\
\hline 4 & Matabubu & 88 \\
\hline 5 & Wundumbatu & $*$ \\
\hline \multirow{4}{*}{ *Data Kel. Wundumbatu masi bergabung dengan Kelurahan Rahandouna }
\end{tabular}

Dalam implementasinya PKH dilakukan melalui beberapa tahapan yang terus berkesinambungan. Mekanisme pelaksanaan PKH meliputi penetapan sasaran (targeting), pertemuan awal dan validasi, penyaluran bantuan, verifikasi komitmen, peningkatan kemampuan keluarga dan pemutakhiran data, (Dirjen Perlindungan dan Jaminan Sosial, 2016:44).

\section{A. Pertemuan Awal Dan Validasi}

Kegiatan pertemuan awal adalah Sosialisasi mengenai Program Keluarga Harapan. Sosialisasi mengenai Program Keluarga Harapan (PKH) di Kecamatan Poasia yang disosialisasikan oleh petugas $\mathrm{PKH}$ belum terealisasi dengan baik, bahkan pejabat Kecamatan Poasia sendiri kurang mengetahui Program Keluarga Harapan dengan baik, berikut kutipan wawancara dengan Bapak Yahya Camat Poasia:

"PKH artinya program pemerintah pusat yang artinya Program Keluarga Harapan, jadi sebenarnya PKH ini pengganti Bantuan Langsung Tunai (BLT). Jadi dia sekarang berbentuk PKH ini program pusat yang diturunkan di daerah-daerah yang kemudian proses-prosesnya itu melalui pendampingpendamping PKH yang ada di Kecamatan kemudian kecamatan membentuk pendamping di Kelurahan tetapi dibawah naungan Dinas Sosial. Jadi PKH adalah kegiatan-kegiatan pemberian bantuan beras". (Wawancara, 10 Desember 2018)

Dari pihak penerima PKH, pengeetahuan mengenai PKH diketahuinya sebagai bantuan untuk anak sekolah untuk masyarakat miskin. Berikut kutipan wawancara yang dikatakan oleh ibu Salviah, penerima bantuan PKH:

"PKH adalah bantuan untuk masyarakat untuk membantu dalam biaya pendidikan karena yang mendapat PKH ini hanya yang memiliki anak yang masih bersekolah kalau tidak ada anak sekolahnya tidak bisa mendapatkan bantuan PKH, tUjuan PKH agar anak bersekolah". (wawancara 4 Desember 2018)

Validasi yakni pencocokan data untuk penetapan peserta yang mendapat PK. Sumber data penetapan sasaran didasarkan atas data hasil verivali data KKS oleh Pusdatin Kesos Kementerian Sosial yang tertuang dalam Undang-Undang 13 tahun 2011 tentang penanganan fakir miskin pasal 8 terkait pendataan fakir miskin.

Koordinator PKH Kota Kendari, bapak Jasman mengatakan :

"pendataan penerima bantuan sosial PKH didasarkan pada data jadi dari pendataan Badan Pusat Stastistik (BPS) selanjutnya pendamping melakukan validasi kepada calon penerima PKH apakah memenuhi kriteria untuk mendapatkan bantuan $P K H$, proses validasi ini sangat penting dalam menentukan penerima manfaat PKH". (Wawancara, 28 November 2018)

Lebih lanjut, Camat Poasia dalam kutipan wawancara mengatakan sebagai berikut:

"proses validasi atau pendataan peserta PKH dilakukan oleh pendamping PKH, 
petugas ini dibentuk masing-masing di kecamatan, jadi petugas PKH ini bekerjasama dengan lurah dan lurah ditindak lanjuti kepada RT RT nya, jadi pendataan itu penerima PKH ini betul-betul menyentuh karena melalui pendataan RT- RT yang difasilitasi dengan dibentuknya PKH disetiap kecamatan". (Wawancara, 10 Desember 2018)

Kementrian Sosial melalui Bank penyalur melakukan penyaluran bantuan sosial secara non tunai kerekening atas nama Keluarga Penerima Mnafaat PKH yang dapat di akses melalui Kartu Kelvarga Sejahtera. Pelaksanaan penyaluran Bantuan sosial dilaksanakan secara bertahap dalam 1 (satu) tahun terbagi dalam 4 (empat) tahap. Bulan penyaluran bantuan yakni Bulan Februari, Mei, Agustus dan November. Besaran komponen yang diterima yakni Rp 1. 890.000 diterima secara bertahap yakni Rp. 500.000 di Bulan Februari, Mei, dan Agustus sedangkan Rp. 390.000 diterima di bulan November atau tahap ke 4 (empat).

Berdasarkan data Dinsos PPKH Kota Kendari total anggaran yang disalurkan untuk PKH Kota Kendari pada tahun 2018 khusus wilayah kecamatan Poasia yakni berjumlah Rp 1.654.590.000. Untuk lebih jelasnya dapat dilihat tabel 2.

\section{Tabel 2}

\section{Anggaran PKH per-Kelurahan di Kecamatan Poasia Tahun 2018}

\begin{tabular}{ccc}
\hline No & Nama Kelurahan & Total Anggaran \\
\hline 1 & Andounohu & Rp 544.300.000 \\
\hline 2 & Anggoeya & $\operatorname{Rp~510.060.000~}$ \\
\hline 3 & Matabubu & $\operatorname{Rp~170.430.000}$ \\
\hline 4 & Rahandouna & Rp 429.800.000
\end{tabular}

Menurut pandangan penerima PKH penyaluran bantuan sosial itu tidak tepat waktu berikut kutipan wawancara dengan ibu Eli :

"proses pengambilan di Bank banyak masalahnya, penyaluran bantuan itu terlambat, saya biasa bingung bantuan terlambat terus padahal bantuan kalau tepat waktukan kami sebagai penerima senang juga karna sudah jelas kapan terimanya". (wawancara, 4 Desember 2018)

Berdasarkan dari pernyataan diatas dapat disimpulkan bahwasanya proses pencairan dana bantuan tidak tepat waktu dan tidak sesuai jadwal saat pemberian dana kepada peserta PKH sehingga masyarakat sering mengeluh mengenai hal tersebut.

\section{B. Verifikasi Komitmen}

Berdasarkan wawancara dengan pendamping PKH ibu Eva mengatakan bahwasanya penerima PKH sudah melakukan kewajibannya baik dalam bidang kesehatan maupun dibidang pendidikan, berikut kutipan wawancaranya:

"Dengan adanya bantuan PKH ini, kalau dulu ibu-ibu yang kurang pergi ke posyandu paling periksakan kesehatannya ke dukun sekarang karena adanya bantuan ini mereka termotivasi untuk pergi ke fasilitas kesehatan karena mereka itu harus capai target kehadirannya $85 \%$ apabila tidak mencapai maka bantuannya akan ditahan Sedangkan dibidang pendidikan para peserta PKH yang malas-malas sekolah akan rajin ke sekolah karena kalau anak penerima PKH tidak rajin atau malas-malas kesekolah kemudian kita verivikasi di sekolah tidak ada anaknya misalkan kehadirannya kurang maka bantuannya juga tidak masuk". (Wawancara, 28 November 2018)

Pernyataan berbeda dikatakan oleh ibu Sia dalam kutipan wawancaranya yaitu:

"saya sudah menjalankan kewajiban sebagai peserta PKH yakni hadir dalam pertemuan dan mendengarkan kalau ada penyuluhan, saya mendapat PKH karena mempunyai anak sekolah jadi pendamping memberitahukan agar anak harus rajin kesekolah agar tetap menjadi penerima PKH". (Wawancara, 4 Desember 2018)

Berdasarkan hal diatas dapat disimpulkan bahwasanya penerima PKH masih ada yang belum memahami dengan baik apa yang menjadi kewajibannya. Sehingga masih terdapat penerima PKH yang belum melaksanakan kewajibannya. 
Vol 2 No 3 August-October 2019. pp. 42 - 56 Journal PUBLICUHO Faculty of Social and Political Sciences Halu Oleo University, Kendari, Southeast Sulawesi, Indonesia. ISSN 2621-1351 (online), ISSN 2685-0729 (print) Open Access at: http://ojs.uho.ac.id/index.php/PUBLICUHO/index

\section{Faktor-Faktor Yang Mempengaruhi Implementasi Program Keluarga Harapan Di Kecamatan Poasia}

Implementasi Program Keluarga Harapan di Kecamatn poasia dipengaruhi dari bebrbagai faktor. Dalam penelitian ini menggunakan teori Edward III yakni sebagai berikut:

\section{Komunikasi}

Komunikasi sangat menentukan keberhasilan pencapaian tujuan dari implementasi Program Keluarga Harapan (PKH) di Kecamatan Poasia. Impelementasi yang efektif terjadi apabila para pembuat keputusan sudah mengetahui apa yang akan mereka kerjakan. Hal itu dapat berjalan dengan baik apabila komunikasi berjalan dengan baik kepada pihak-pihak yang terkait.

Komunikasi didalam implementasi suatu program merupakan hal yang penting. Dalam meneruskan pesan-pesan kebawah dalam suatu organisasi atau dari suatu organisasi ke organisasi lainnya, para komunikator dapat menyampaikan baik secara sengaja maupun tidak sengaja. Lebih dari itu jika sumber-sumber informasi yang berbeda memberikan interpretasi yang berbeda, para pelaksana akan menghadapi kesulitan dalam melaksanakan tujuan kebijakan.

Sebagaimana yang diungkapkan Koordinator PKH Kota Kendari, Pa jasman mengatakan bahwa:

"yang melaksanakan PKH di Kecamatan Poasia yakni pendamping berkoordinasi dengan camat" (Wawancara, 28 November 2018)

Namun dalam kutipan wawancara dengan camat Poasia bapak yahya mengatakan bahwa tidak ada koordinasi dengan pendamping, adapun kutipan wawancaranya yakni:

"Yang salama ini memang petugas PKH atau pendamping kecamatan itu langsung turun ke kelurahan saya tidak tahu kalau di kelurahan mereka ada selalu koordinasi kalau ditingkat kecamatan tidak ada". (Wawancara, 10 Desember 2018)

Program Keluarga Harapan (PKH) yang diterapkan oleh pemerintah melalui Kementerian Sosial, pada dasarnya program ini bertujuan untuk membantu meningkatkan kualitas hidup masyarakat miskin khususnya dibidang kesehatan, pendidikan dan kesejahteraan sosial. Namun kenyataan dilapangan penulis melihat tidak semua masyarakat mengetahui adanya PKH ini keterlibatan stakeholder dalam penyampaian progam ini menjadi kunci utama dalam kesuksesan program tersebut. Bila dikaitkan dengan yang ada di lapangan sosialisasi hanya dilakukan kepada penerima Program Keluarga Harapan (PKH).

Sebagaimana yang diungkapkan oleh salah satu penerima PKH di Kecamatan Poasia, beliau mengatakan bahwa:

"saya baru mengetahui Program Keluarga Harapan waktu saya menjadi penerima PKH karena kalau sosialisasi di masyarakat itu tidak ada". (Wawancara, 8 Desember 2018)

Adapun bentuk sosialisasi pelaksanaan PKH di Kecamatan Poasia sebagaimana yang diungkapkan pendamping yakni:

"Sosialisasi itu pada saat awal validasi itukan semua sudah ada undangannya yang dapat PKH undanganya itu langsung dari Kementrian bukan dari Dinas jadi yang bertanda tangan disitu itu Dirjen nanti kami pendamping yang edar kepada penerima PKH, KPM hadir di pertemuan awal itu nanti disitu baru kita sosialisasi bentuk program seperti apa". (Wawancara, 28 November 2018)

Berdasarkan hasil penelitian tersebut dapat disimpulkan bahwa komunikasi mengenai implementasi PKH belum berjalan dengan baik, hal ini dapat dilihat dari pendamping yang tidak berkoordinasi dengan camat Poasia. Berdasarkan kesimpulan hasil wawancara diatas peneliti melihat bahwa teori Edward III belum sesuai fakta yang ada dilapangan mengenai komunikasi untuk PKH, yang dimana kebijakan menuntut komunikasi sangat menentukan keberhasilan pencapaian tujuan dari implementasi. 


\section{Sumber Daya}

Ketersediaan sumber daya dalam melaksanakan sebuah program merupakan salah satu faktor yang harus selalu di perhatikan. Dalam hal ini sumberdaya yang dimaksud adalah sumberdaya manusia, sumberdaya financial maupun sumberdaya dalam hal sarana dan prasarana. Untuk mendukung jalannya Implementasi Program Keluarga harapan di Kecamatan Poasia. Indikator sumberdaya terdiri dari beberapa elemen yaitu:

\section{a. Sumberdaya Manusia}

Sumberdaya yang utama dalam implementasi program adalah sumberdaya manusianya (staf). Kegagalan yang sering terjadi dalam implementasi kebijakan salah satunya disebabkan oleh manusianya yang tidak mencukupi, memadai, ataupun tidak kompeten dibidangnya. Berkenaan dengan sumberdaya manusia, hasil wawancara dengan Koordinator PKH Kota Kendari beliau mengatakan bahwa:

"jumlah staf yang terlibat kalau untuk saat ini cukup karena daerah mudah keahlian pendamping juga banyak kalau pendamping PKH itu pendamping yang harus serba bisa, pertama harus pintar komputer sudah pasti, kalau perlu pendamping itu harus bisa berbahasa asing karena program CCT/PKH ini bukan hanya program Indonesia tapi juga juga program dunia kan baru- baru ini ada beberapa Negara yang melakukan studi banding meneganai program ini jadi pendamping PKH itu dituntut harus meningkatkan kapasitas diri". (Wawancara, 28 November 2018)

Selanjutnya berkenaan dengan sumberdaya yang bertugas mengimplementasikan PKH di Kecamatan Poasia, Bapak Yahya sebagai camat Poasia mengatakan bahwa:

"Saya kira pelaksana PKH cukup berkompeten dalam bidangya karena para pendamping PKH melalui tahap seleksi yang diadakan langsung oleh Kementrian Sosial sehingga mereka yang menjadi pendamping memiliki kemampuan untuk menjelaskan tugasnya". (Wawancara, 10 Desember 2018)

\section{b. Sumberdaya Peralatan}

Sumberdaya peralatan merupakan sarana yang digunakan untuk operasionalisasi implementasi suatu yang meliputi gedung, tanah, dan sarana semuanya akan memudahkan dalam memberikan pelayanan dalam implementasi kebijakan. Berkenaan dengan sarana dan prasarana hasil wawancara dengan Koordinator PKH Kota Kendari bapak Jasman mengungkapkan bahwa:

"mengenai sarana dan prasarana cukup memadai Kementrian Sosial memfasilitasi komputer, server, pemerintah daerah memfasilitasi ruangan, fasilitas AC, kursi dan kertas, jadi dalam melaksanakan tugas berjalan dengan baik karena sarana dan prasarana cukup memadai (Wawancara, 28 November 2018)

Berbeda dengan yang dikatakan pendamping PKH, ibu Eva mengungkapkan bahwa: "Kalau sarana memang kurang, kita ada materi FDS kami menggunakan uang pribadi untuk fotokopi materi, kita menggunakan leptop sendiri, peralatan terbatas sekali yang ada saja kami gunakan". (Wawancara, 28 November 2018)

Berdasarkan hal tersebut peneliti melihat bahwa teori Edward III belum sesui fakta yang ada dilapangan yang dimana kebijakan menuntut sumber daya peralatan untuk memudahkan dalam memberikan pelayanan dalam implementasi kebijakan belum terpenuhi.

\section{c. Disposisi}

Disposisi dikatakan sebagai "kemauan, keinginan dan kecendrungan para pelaku kebijakan untuk melaksanakan kebijakan secara sungguh-sungguh sehingga apa yang menjadi tujuan kebijakan dapat diwujudkan".

Berkenaan dengan sikap pelaksana dalam hal ini pendamping PKH menurut Koordinator PKH Kota Kendari bapak Jasman mengatakan bahwa:

"Mengenai sikap pendamping itu dalam mendampingi peserta PKH itu tinggi karena pendamping itu punya motto "pantang pulang sebelum tugas tuntas". (Wawancara, 28 November 2018)

Menurut salah satu penerima PKH ibu Eli pendamping dalam mendampingi penerima $\mathrm{PKH}$, beliau mengungkapkan bahwa: 
Vol 2 No 3 August-October 2019. pp. 42 - 56 Journal PUBLICUHO Faculty of Social and Political Sciences Halu Oleo University, Kendari, Southeast Sulawesi, Indonesia. ISSN 2621-1351 (online), ISSN 2685-0729 (print) Open Access at: http://ojs.uho.ac.id/index.php/PUBLICUHO/index

"pendamping orangnya baik,dan ramah. Pendamping dalam mendampingi kami itu baik seperti apabila ada masalah dana bantuan tidak masuk kerening penerima PKH pendamping memabantu mengurusnya kemudian selalu memberikan motivasi kepada kami untuk menjadi ibu rumah tangga yang baik dalam mengurus keluarga". (Wawancara, 28 November 2018)

Hal berbeda diungkapkan oleh camat Poasia bapak Yahya dalam kutipan wawancaranya mengatakan:

"pendamping sudah tugasnya mendampingi penerima PKH karena sudah ada honornya karena mereka bukan pendamping-pendamping yang tidak dibayar mereka dibiayai oleh Dinas Sosial yang sudah dianggarkarkan untuk mendampingi penerima PKH dengan baik. (Wawancara, 10 Desember 2018)

Berdasarkan kesimpulan hasil wawancara diatas peneliti melihat bahwa teori Edward III telah sesuai fakta yang ada dilapangan mengenai disposisi pendamping dalam mendampingi keluarga penerima manfaat PKH, yang dimana kebijakan menuntut para pelaku kebijakan untuk melaksanakan kebijakan secara sungguh-sungguh sehingga apa yang menjadi tujuan kebijakan dapat diwujudkan

\section{d. Struktur Birokrasi}

Struktur birokrasi yang bertugas mengimplementasikan kebijakan memiliki pengaruh yang signifikan terhadap implementasi kebijakan. Salah satu aspek struktur yang penting dari setiap organisasi adalah adanya prosedur operasi standar (standard operating procedures atau SOP). Berkenaan dengan SOP menurut Koordinator PKH Kota Kendari mengungkapkan bahwa:

"Mengenai SOP yang digunakan sebagai petunjuk pelaksanaan PKH yakni ada pedoman umum pelaksana PKH dari pusat karena itu sudah menjadi ketentuan yang harus kita ikuti dalam menjalankan tugas". (Wawancara, 28 November 2018)

Berdasarkan kesimpulan hasil wawancara diatas peneliti melihat bahwa teori Edward III telah sesuai fakta yang ada dilapangan yang dimana SOP adalah salah satu aspek struktur yang penting dari setiap organisasi.

\section{KESIMPULAN}

Berdasarkan hasil penelitian ini menunjukan bahwa Implementasi kebijakan Program Keluarga harapan (PKH) di Kecamatan Poasia secara umum belum terlaksana dengan baik berdasarkan pengetahuan dan sosialisasi PKH yang dilakukan oleh pendamping; Proses validasi dalam menentukan peserta PKH; Proses pendistribusian dana PKH kepada penerima PKH dilakukan melaui bank penyalur; Kewajiban peserta PKH dalam melaksanakan kewajibannya belum memahami dengan baik; sedangkan faktor yang mempengaruhi implementasi program tidak selalu mempengaruhi. Kesimpulan penelitian menunjukan bahwa Implementasi kebijakan Program Keluarga harapan (PKH) di Kecamatan Poasia secara umum belum terlaksana dengan baik.

\section{SARAN}

Berdasarkan uraian kesimpulan diatas dapat direkomendasikan saran-saran sebagai berikut:

1. Pelaksana PKH diharapkan berkoordinasi dengan pejabat-pejabat kecamatan sehingga pelaksanaan PKH dapat berjalan dengan baik.

2. Pelaksana PKH diharapakan mensosialisasikan PKH tidak hanya kepada peserta PKH tetapi juga harus mensosialisasikan PKH kepada pihak-pihak lain pejabat kecamatan, perangkat kelurahan dan warga masyarakat secara luas sehingga mendapat dukungan dari masyarakat secara luas.

3. Perlu diadakan pemutakhiran data secara benar sehingga tidak ada lagi masyarakat mampu yang mendapatkan bantuan ini sebab bantuan ini diperuntukan bagi masyarakat miskin. 


\section{DAFTAR PUSTAKA}

Agustino, Leo. 2006. Dasar-Dasar Kebijakan Publik. Bandung: CV Alfabeta Bandung

Dwiyanto, Agus. 2005. Mewujudkan Good Governance Melalui pelayanan public Jogjakarta: Gajah Mada Universitas press

Daniel A. Mazmanian dan Paul A. Sabatier (santosa 2012:42): Implementasi kebijakan

Dirjen Perlindungan dan Jaminan Sosial, 2016:44. "MEKANISME PELAKSANAAN. Referensi Pedoman Pelaksanaan PKH Tahun 2016, Bab III - VI"

Edwards III, George C. 1980. Implementing Public Policy. Washington: Congressional Quarterly Inc.

Elwan L.O.M. 2018. Rekomendasi Kebijakan Program Kota Layak Anak di Kota Kendari. Journal Publicuho, 2(1), 15-29. DOI: http://dx.doi.org/10.35817/jpu.v2i1.5987

Miles, Matthew B., and Huberman, A. M., 1994. Qualitative Data Analysis: An Expanded Sourcebooks. London: Sage Publications.

Moleong,L.J.(2011). Metodologi Penelitian Kualitatif Edisi Revisi. Bandung: PT Remaja Rosdakarya.

Wahab, Solichin Abdul. 2012. Analisa Kebijakan: Daro Formulasi Ke Penyusunan Model-Model Implementasi Kebijakan Publik. Jakarta: Bumi Aksara

Widodo, Budi. 2008. Analisis Kebijakan Publik. Konsep Dan Aplikasi Analisis Proses Kebijakan Publik. Malang : Bayu Media

Winarno, Agus.2005. Kebijakan Publik : Teori Dan Proses. Jogjakarta: Media Presindo 